\title{
Comprehensive Environmental Risk Assessment of Heavy Metals in an Abandoned Dye Factory of China Using SERA Methodology Based on Source Apportionment
}

\section{Fangfang Miao}

North China Electric Power University

Yimei Zhang ( $\sim$ mist1218@tom.com )

North China Electric Power University

Shuai Li

North China Electric Power University

Yaxiao Duan

North China Electric Power University

Yuxian Lai

North China Electric Power University

Qinglu Fang

North China Electric Power University

Zhiying Li

North China Electric Power University

Qianguo Lin

The University of Edinburgh

Yu Li

North China Electric Power University

Original research

Keywords: Soil heavy metal, Quantitative source apportionment, Ecological risk, Human health risk, Source contribution

Posted Date: February 4th, 2021

DOl: https://doi.org/10.21203/rs.3.rs-167605/v1

License: (9) This work is licensed under a Creative Commons Attribution 4.0 International License. Read Full License 

1 Comprehensive environmental risk assessment of heavy metals in an abandoned 2 dye factory of China using SERA methodology based on source apportionment

3 Fangfang Miao ${ }^{\mathrm{a}}$, Yimei Zhang ${ }^{\mathrm{a}, \mathrm{b} *}$, Shuai $\mathrm{Li}^{\mathrm{b}}$, Yaxiao Duan ${ }^{\mathrm{a}}$, Yuxian Lai ${ }^{\mathrm{b}}$, Qinglu Fang ${ }^{\mathrm{a}}$, Zhiying Li $^{\mathrm{a}}$, Qianguo Lin ${ }^{\mathrm{b}, \mathrm{c}}$ $4 \quad \mathrm{Yu} \mathrm{Li}^{\mathrm{a}}$

$5 \quad{ }^{a}$ MOE Key Laboratory of Resources and Environmental System Optimization, College of Environmental Science and Engineering, North China Electric Power University, Beijing, 102206, China

${ }^{\mathrm{b}}$ Laboratory of Environmental Remediation and Functional Material, Suzhou Research Academy of North China

Electric Power University, Suzhou, Jiangsu, 215213, China

'Business School, The University of Edinburgh, Edinburgh,EH8 9JU, UK

E-mail: zhangym@ncepu.edu.cn; Fax:86-0512-67332655; Tel: 86-0512-67332668

Address: Suzhou Research Academy of North China Electric Power University, Suzhou, Jiangsu, 215123, P.R.China

\section{Abstract}

Soil heavy metal contaminated sites with multiple sources of pollution have caused worldwide public concern.

However, the lack of correlation of risk assessment or source identification of heavy metal leads to unclear direction

of source governance. Although previous studies have involved different risk assessment, few attempts have been made to establish a link between them. In order to design a comprehensive risk assessment system, it is necessary to identify the specific source risks and the correlation and comparison between environmental risk assessment. In this paper, a methodology was established by combining source apportionment of ecological risks and human health risks (SERA) to characterize the sources and source-specific risks of heavy metals in soil. Positive matrix factorization (PMF) model was used to identify and classify potential sources of heavy metals in the study area. According to the results, they will be incorporated into the environmental risk model to evaluate environmental risk of the identified 
values, indicating a moderate enrichment. It was worth noting that the source contributed ecological risk index (SCEI) of $\mathrm{Hg}$, with the value of 51.16 contributed mainly by the pollutant sources of waste treatment, has reached moderate ecological risk. The $\boldsymbol{S C E I}$ of Cd contributed by industrial activities (the wastewater and dyeing process) showed the most predominant source of contribution. The source contributed human health risk index (SCHI) of As contributed most by pollutant sources of agriculture activities. Overall, the modified total health risk posed by soil heavy metals

$\boldsymbol{S C H I}$ was $1.11 \mathrm{E}+00$, showing potential risk to the residents. This study provides a new insight for the treatment of mutil-sources of soil heavy metal pollution and also some reference value for the improvement of the risk assessment system.

the main finding: Exploring a methodology (SERA) to quantitatively characterize the relationship between pollutants sources and environmental risk assessment based on source contribution.

\section{Keywords:}

\section{Introduction}

Soil is the most important natural resource of a country and the material basis of environment where human beings

live on(Liang etal., 2017). However, with the increasing agricultural production, industrial activities and human activities, great pressure was put on the soil quality continually, resulting in direct soil pollution, especially soil heavy metal pollution (Ihedioha etal., 2017). The heavy metal pollutants in soil mainly include $\mathrm{Hg}, \mathrm{Cd}, \mathrm{Pb}, \mathrm{Cr}, \mathrm{Cu}, \mathrm{Ni}, \mathrm{Co}$,

41 Sn and the metal-like As. Different from other pollution, heavy metal pollution is not easy to be leached with water and decomposed by microorganism in soil (Xie etal., 2016). There are four main ways in which metals enter the soil: atmospheric deposition (natural and man-made), fertilizers containing metal impurities, industrial emission, and irrigation of contaminated water. Afterwards heavy metals enter the food chain through accumulation in plants and have obvious biological enrichment, posing risks to the ecosystem and human health (Han etal., 2006). In addition, 
metals are often tightly bound to soil solids, and even small increases in the current concentration of heavy metals in

the soil can have potentially adverse effects on soil quality (Islam etal., 2017). With the increasingly serious soil pollution, it is important to predict the accumulation trend of heavy metals in soil and understand the risk of heavy metal pollution. Therefore, it is of far-reaching significance to effectively assess the pollution situation, including potential local ecological risks, identify potential pollution sources, so as to provide information for soil pollution control (CSC, 2016).

So far, many research groups have been working on the investigation of soil pollution (Couto et al., 2018). However, most of these studies focus on agricultural pollution or water pollution, and there are relatively few studies on abandoned factory soil pollution. Even if there are some studies on the classification of pollution sources of it. The studies organically combined the contribution rate of source analysis with ecological risk assessment and human health risk has few been reported, let alone systematic relevance between them (Xiao et al., 2019). In order to better understand the pollution level of heavy metals in soil, Kriging interpolation method was often used to obtain the concentration distribution of heavy metals in soil. In addition, enrichment factor (EF) and potential ecological risk index (EI) were also calculated to obtain the ecological and environmental information of soil pollution (Tian et al., 2017; Nazzal et al., 2016). To reduce the hazards of heavy metals, it is necessary to better understand the characteristic distribution, pollution sources and environmental risks of heavy metals in the environment (Jiang et al., 2017;Niu et al., 2020). Identifying potential pollution sources of heavy metals is the basic premise for designing targeted pollution control measures. Although source apportionment and environmental risk assessment of heavy metal pollution have been carried out in many studies, the study about source-specific health risk and potential ecological risk based on the contribution rate of source analysis are few. Positive matrix factor decomposition (PMF) is a commonly used method in pollution source analysis, which is widely used in various media such as atmosphere, hydrosphere and soil sphere (Liang et al., 2017a). It can be applied to apportion the potential sources of heavy metals (Norris et al., 2014). 
uncertainty inherent in environmental data (Paatero and Tapper, 1994). Quantitative source analysis and its contribution research is helpful to identify the main pollution sources and quantify their contribution rate (Yang et

71 al., 2019). The objective of this study is to conduct a combination of source analysis and environmental risk assessment methodology (SERA) to characterize the soil heavy metal pollution levels of the source and sourcespecific risk. Firstly, the contribution rate of pollution sources was used for risk sharing. Secondly, the assessment results were incorporated into the environmental risk assessment model to identify heavy metals from identified sources. Thirdly, the heavy metals with large contribution from pollution sources and high risk level were screened out. Finally, targeted risk reduction strategies could be developed by the above information. It provides theoretical basis for the government to control heavy metal pollution scientifically (Huang etal., 2006; Luo etal., 2011).

The city studied in this paper (Suzhou) has a thriving ecotourism industry, and there are abandoned industrial polluted sites that have not been treated. Therefore, it is necessary to pay attention to the environmental health risks in this region. The integrated framework SERA method combined source apportionment and source-specific environmental risk assessment was shown in Fig. 1.

This paper mainly deals with: (i) the distribution of heavy metal concentration in soil sampling sites in Suzhou with reference to the Soil Guide of China (National Environmental Protection Agency, 1995);(ii) Multivariate statistics of EF and EI were used to analyze the pollution levels; (iii) identification of potential sources of HMs pollution through PMF models (Kumar et al., 2019);(iv) Calculation of source-contributed ecological risk index (SCEI) and human health risk index $(\boldsymbol{S C H I})$. This study can provide reference for soil remediation and protection

87 design in the study area, and also provide reference for policy formulation and protection research on soil heavy metal pollution in other areas. 


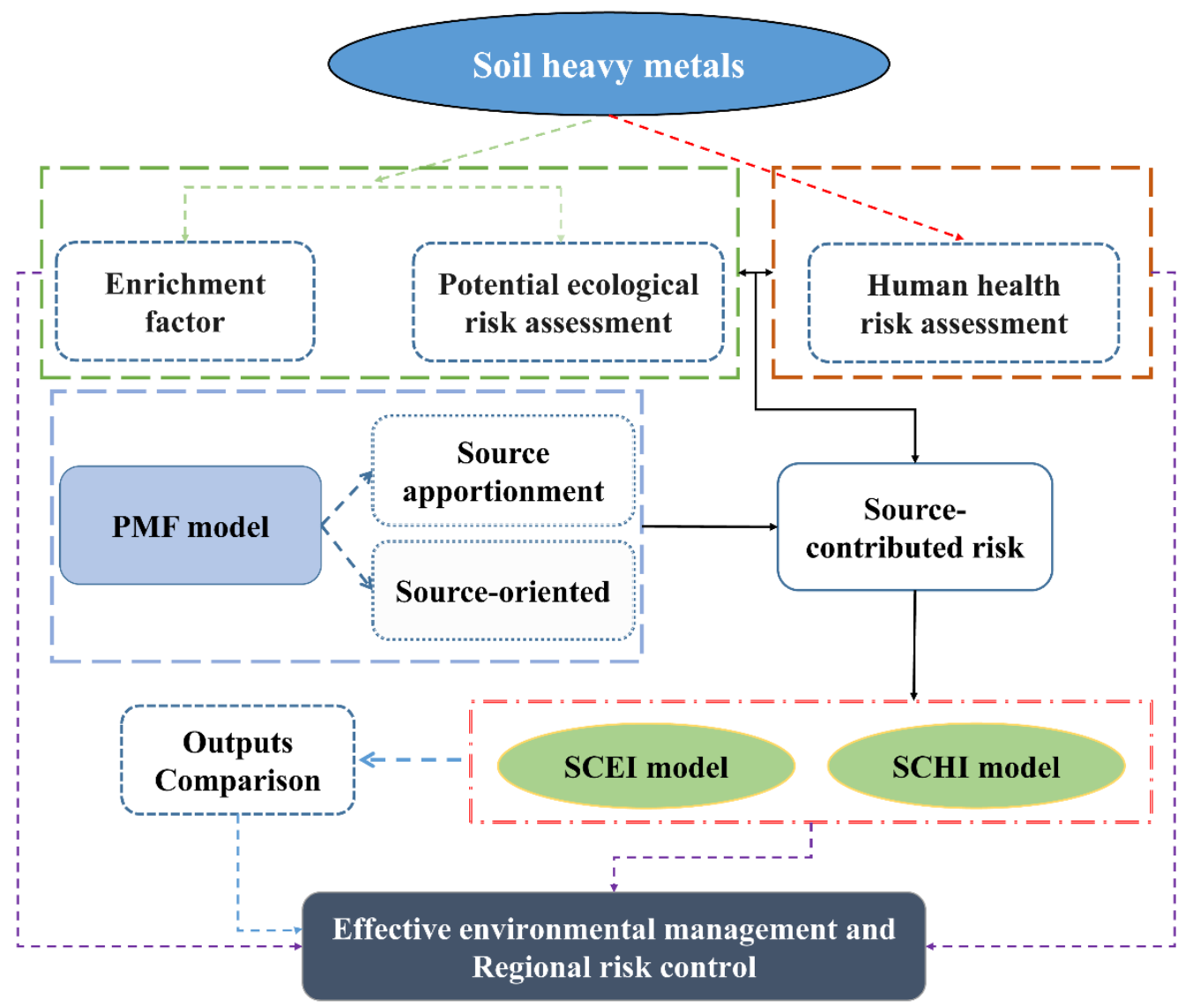

90 Fig.1. Frameworks of the source apportionment and environmental risk assessment methodology (SERA). SCEI model: source-

91 contributed ecological risk index model; SCHI model: source-contributed health risk index model.

\section{2. Materials and methods}

\subsection{Study area and sampling}

Suzhou is located in the middle of the Yangtze river delta, the southeast of Jiangsu province, located at $119^{\circ} 55^{\prime} \mathrm{E}$

to $121^{\circ} 20^{\prime} \mathrm{E}, 30^{\circ} 47^{\prime \prime} \mathrm{N}$ to $32^{\circ} 02^{\prime} \mathrm{N}$, east of Shanghai, south of zhejiang, west of taihu lake, north of the Yangtze river,

the total area of 8657.32 square kilometers. The city is low-lying and flat, with many rivers and lakes. Most of the

water surface of taihu lake is in suzhou. Rivers, lakes and beaches account for $36.6 \%$ of the city's land area. Suzhou

is a subtropical monsoon maritime climate, with an average temperature of $17.8^{\circ} \mathrm{C}$ and precipitation of $1369.2 \mathrm{~mm}$ soil with small deformation and high strength is mainly grey, with compact texture. 


\subsection{Sample collection and chemical analysis}

In order to find out the sources of heavy metals in the study area, 30 sampling points $(0-7 \mathrm{~cm})$ were collected for measurement in Suzhou in October 2019, with a density of $1 \mathrm{~km}$ (Fig .S1). The soil samples were taken back to the laboratory and naturally dried and ground crushing, first through a 20 mesh sieve for $\mathrm{pH}$ analysis, then used for the determination of physical and chemical properties (Pal etal., 2019). The processed soil samples were dissolved in the mixture acid solution $\left(\mathrm{HNO}_{3}-\mathrm{HF}-\mathrm{HClO}_{4}\right)$ at a high temperature of $210^{\circ} \mathrm{C}$ for 4 h (Bryanin etal., 2019). Soil $\mathrm{pH}$ was determined with a ratio of 2:5 (w/v) soil/water mixture using a $\mathrm{pH}$ meter (Cheng et al. 2018). The soil organic matter $(\mathrm{OM})$ content was determined by the chromic acid titration method. The content of heavy metals $\mathrm{As}, \mathrm{Cd}, \mathrm{Cr}, \mathrm{Hg}$ and $\mathrm{Pb}$ in soil samples were determined by atomic absorption spectrometry (Agilent Technologies 280FS AA). Each batch of samples were evaluated by reagent blanks to reduce errors for quality assurance (Jiang etal., 2019).

\subsection{The research approach of study area}

\subsubsection{Ecological Evaluation}

\subsubsection{Enrichment factor (EF)}

Enrichment factor is a method often used to express the enrichment degree of elements in atmospheric particles, and to judge and evaluate the sources (natural and anthropogenic) of elements in soil (Chen teal., 2018). It can reflect the effect of soil contamination on human health, which is also an important indicator for quantitative evaluation of pollution degree and pollution source (Pan etal., 2016). It selects elements that meet certain conditions as reference elements (or standardized elements) (Couto et al., 2018). The ratio of the concentration of pollution elements in the sample to the concentration of reference elements and the ratio of the concentration of both in the background area is the enrichment factor (Couto et al., 2018). EF was calculated as the formula below:

$$
\mathrm{EF}=\frac{[\text { metal } / \mathrm{Zn}]_{\text {sampled }}}{[\text { metal } / \mathrm{Zn}]_{\text {standard }}}
$$

In the formula $[\mathrm{metal} / \mathrm{Zn}]_{\text {sampled }}$ is the sampled concentrations of heavy metals divided by reference parameter; 
$[\text { metal/Zn }]_{\text {standard }}$ represents the standard value of soil heavy metals divided by the reference standard; $\mathrm{Zn}$ was used as the reference paremeter (Barbieri etal., 2016).

\subsubsection{Potential ecological risk index (PERI)}

In this paper, the standardized heavy metal $\mathrm{T}_{\mathrm{r}}^{\mathrm{i}}$ developed by Hakanson was used for evaluation basis, which was set as the toxicity of heavy metals (Hakanson et al., 1980). The values of $\mathrm{T}_{\mathrm{r}}^{\mathrm{i}}$ for different heavy metals were shown in table S1. It was calculated by the following equation for the potential ecological risk index of an individual metal $\mathrm{E}_{\mathrm{r}}^{\mathrm{i}}$

$$
\mathrm{E}_{\mathrm{r}}^{\mathrm{i}}=\mathrm{T}_{\mathrm{r}}^{\mathrm{i}} \times \frac{\mathrm{c}}{\mathrm{c}_{0}}
$$

Where c represented the measured concentration of heavy metal and $\mathrm{c}_{0}$ was the background value of heavy metal in soil (Sartipi Yarahmadi and Ansari, 2018). $\mathrm{E}_{\mathrm{r}}^{\mathrm{i}}$ represented the environmental risk index of heavy metal $\mathrm{i}$ and $\mathrm{T}_{\mathrm{r}}^{\mathrm{i}}$ represented the toxicity response coefficient of heavy metal i, which mainly reflects the toxicity level of heavy metals and the sensitivity of environment to heavy metal pollution.

The potential ecological risk index (EI), based on heavy metal concentration and toxicity, was conducted to calculate the integrated potential environmental risk for the total hazard heavy metals (Zhu etal., 2012; Wu etal., 2017). Levels of them were classfied for five standards based on table S2 (Sartipi Yarahmadi and Ansari, 2018). The following equation was used for the calculation of RI.

$$
\mathrm{RI}=\sum \mathrm{E}_{\mathrm{r}}^{\mathrm{i}}
$$

\subsubsection{Source apportionment of heavy metals by PMF model}

The positive definite matrix factorization (PMF) method was developed by the Finnish scientists paatero and tapper on the basis of FA. It was also one of the source analysis methods recommended by the U.S. Environmental Protection Agency (Paatero etal., 2010). The positive matrix factorization (PMF) was a factor analysis method based on the least square method, which decomposed the matrix without negative constraints and can be optimized by using the 
standard deviation of data (Chen etal., 2011). This method did not rely on the chemical composition spectrum analysis

of pollution sources, but took the data sets of multiple soil samples and heavy metal elements as a matrix, and then decomposed the matrix into the contribution rate matrix and the source composition spectrum matrix (Dong etal., 2018; Franco etal., 2009). Through non negative constraint factor analysis and iterative calculation with the least square method, the objective function was minimized to solve chemical mass balance (CMB) between the measured heavy metal concentration and pollution source (Guan etal., 2018). Compared with the traditional factor analysis method (such as FA-MLR), the PMF method made non negative constraints on the factor load and factor score in the solution process, so as to avoid the negative value in the result of matrix decomposition, so that the obtained source component spectrum and source contribution rate can be explained and had clear physical significance (Lv etal., 2019). In addition, the PMF method did not require the measurement of the source component spectrum, and used error estimates for each individual data point in order to deal with missing and inaccurate data more reasonably

(Mamut etal., 2017). The data entered into the program include concentrations and equation-based uncertainties (Jingchun etal., 2014).

Compared with the traditional source apportionment methods, the PMF method could weight all data that can analyze the contribution rate of target variables (Tian et al., 2018). The sample metal concentration data matrix was defined as:

$$
C_{x}^{t}=\sum_{y=1}^{p}\left(g_{x y} f_{x}^{t}+e_{x}^{t}\right)
$$

where, the $\boldsymbol{C}_{\boldsymbol{x}}{ }^{\boldsymbol{t}}$ represented concentration of the $\boldsymbol{t}$ compound at the sampling point $\boldsymbol{x} ; \boldsymbol{g}_{x y}$ represented contribution rate of the $y_{t h}$ source at the sampling point $\boldsymbol{x} ; \boldsymbol{f}_{\boldsymbol{y}}{ }^{t}$ was the mass fraction of the $\boldsymbol{y}_{\boldsymbol{t} \boldsymbol{t}}$ source at the metal $\boldsymbol{t} ; \boldsymbol{e}_{\boldsymbol{x}}{ }^{t}$ was the deviation

of the metal $\boldsymbol{t}$ at sample point $\boldsymbol{x}$; Objective function $\boldsymbol{Q}$ was defined by Eq. (5) (Duan etal., 2020).

$$
Q=\sum_{x=1}^{n} \sum_{t=1}^{m}\left(e_{x}^{t} / u_{x}^{t}\right)^{2}
$$

where the $\boldsymbol{u}_{\boldsymbol{x}}{ }^{t}$ was the uncertainty of the metal $\boldsymbol{t}$ at the sampling point $\boldsymbol{x}$ (De Miranda et al., 2018). 
concentration of heavy metals was less than or equal to the method detection limit (MDL), uncertainty (Unc) will be

170 If the concentrations of heavy metals were higer than the MDL, the equation was run as follows (USEPA,2014):

171 the $\mathrm{Unc}=\sqrt{(\text { Error fraction } \times \text { concentration })^{2}+(0.5 \mathrm{MDL})^{2}}$

$172 \quad$ 2.3.3. Environmental risk assessment based on source-oriented model

\subsubsection{Source-contributed potential ecological risk index model (SCEI)}

174 PMF-based RI model in this study was established to quantify potential ecological risks of heavy metals from the identified sources in the area. The source contributed potential ecological risk was evaluated with the combination of quantitative source apportionment and ecological risk assessment. The ecological risk assessment of every pollution source could clearly evaluate the hazards to the environment of each specific source of pollution. The source contributed ecological risk (SCEI) would be calculated by Eq. (8).

$179 \quad S C E I=R I \times g \%$

Where $\boldsymbol{S C E I}$ was the source contributed ecological risk index of each sources, $\mathrm{g} \%$ referred to the percentage of source contribution.

The contribution rate of source $\boldsymbol{m}$ was calculated by Eq. (9).

$$
g \%=\left(A \mathrm{~m} / \sum_{\mathrm{m}=1}^{p} A_{m}\right) \times 100 \%
$$

where, the $\boldsymbol{A}_{\boldsymbol{m}}$ referred to the regression coefficient for $\boldsymbol{y}_{\boldsymbol{t}}$ source (Liu et al.,2018; Larsen and Baker, 2003).

\subsubsection{Source-contributed human health risk index model (SCHI)}

Exposure to heavy metals may cause potential adverse effects on human health due to heavy metal toxicity.

Therefore, certain risk assessment model was developed by the USPEA and used frequently for the risk assessment. 


$$
\begin{aligned}
& H I=\sum_{i=1}^{3} H Q=\sum_{i=1}^{3} A D D_{i} / R f D_{i} \\
& T H I=\sum H I
\end{aligned}
$$

$\boldsymbol{R} \boldsymbol{f D}$ was the reference dose (mg/kgd); The hazard index (HI) is the sum of $\boldsymbol{H Q s}$ (Eq. (10)). The total hazard index

(THI) is the sum of $\boldsymbol{H I}$ (Eq. (11)). The other parameters were provided by supplementary material in Table S3.

Combined with quantitative source apportionment and health risk assessment, the source- ontributed health risk

(SCHI) was calculated by Eq. (12) and Eq. (9).

$S C H I=H I \times g \%$

\subsection{Statistical analysis}

Microsoft Excel (version 2010, USA) was used for calculations. The spatial distribution of SHMs was mapped by the Surfer v.12.0 (Golden Software Inc., CO, USA) and ArcGIS 10.7 software. SPSS Statistics 25 (IBM Inc., CO,USA) was used to conduct the analyses and to obtain the relevant parameters. The data underwent by EPA-PMF 5.0 to assess the sources of SHMs with a 95\% confidence interval (significance $\mathrm{p}<0.05$ ). Crystal Ball software (Version 2000, Decisioning, Denver, CO, USA) was employed for uncertainty analysis.

\section{Results and discussion} interpolation technique. The mean concentrations of different heavy metals decreased following the order: $\mathrm{Pb}>\mathrm{As}>$

$\mathrm{Cd}>\mathrm{Cr}>\mathrm{Hg}$. Compared with the background value, the mean concentrations of $\mathrm{Cd}$ and $\mathrm{Hg}$ were relatively higher 
209 Additionally, the highest $\boldsymbol{C} \boldsymbol{V}$ of heavy metals turned out to be $\mathrm{Hg}$ followed by As and $\mathrm{Cd}$, which indicated that the 210 extensive variation may be affected by multiple factors, especially the anthropogenic activities (Fu et al., 2014).

211 Furthermore, the concentrations of other heavy metals $(\mathrm{Cr}, \mathrm{Pb})$ were close to the background values and the $\boldsymbol{C V}$ of

212 them were lower than $50 \%$, indicating moderate variability in the study area.

\section{Table 1}

214 Summary statistics for heavy metal concentrations $\left(\mathrm{mg} \mathrm{kg}^{-1}\right)$ in soils.

\begin{tabular}{|c|c|c|c|c|c|}
\hline Element & $\mathbf{P b}$ & $\mathbf{H g}$ & $\mathrm{Cr}$ & Cd & As \\
\hline Min & 5.46 & 0.02 & 0.10 & 1.81 & 2.08 \\
\hline Max & 81.57 & 1.51 & 1.59 & 28.95 & 86.88 \\
\hline Mean & 28.42 & 0.18 & 1.03 & 8.65 & 17.75 \\
\hline Median & 24.71 & 0.13 & 1.12 & 8.25 & 14.40 \\
\hline Variance & 145.04 & 0.033 & 0.073 & 16.51 & 124.33 \\
\hline $\mathrm{SD}$ & 12.04 & 0.18 & 0.27 & 4.06 & 11.15 \\
\hline $\mathrm{CV}$ & 0.42 & 1 & 0.26 & 0.47 & 0.63 \\
\hline$B V^{a}$ & 26.20 & 0.053 & 77.80 & 0.126 & 10.0 \\
\hline $\mathrm{AV}^{\mathrm{b}}$ & 27.0 & 0.071 & 61.0 & 0.097 & 11.0 \\
\hline Chinese soil criteria $^{c}$ & 250 & 2.5 & 150 & 0.3 & 30 \\
\hline Percent & 0.085 & 2.40 & 0 & 67.65 & 0.775 \\
\hline
\end{tabular}

216 a BV-Background value of Jiangsu (Ma et al., 2015);

217 b AV-Average value of China (Wang et al. 2019a);

$218{ }^{\mathrm{c}}$ Chinese soil criteria (CNEPA(1995)). 

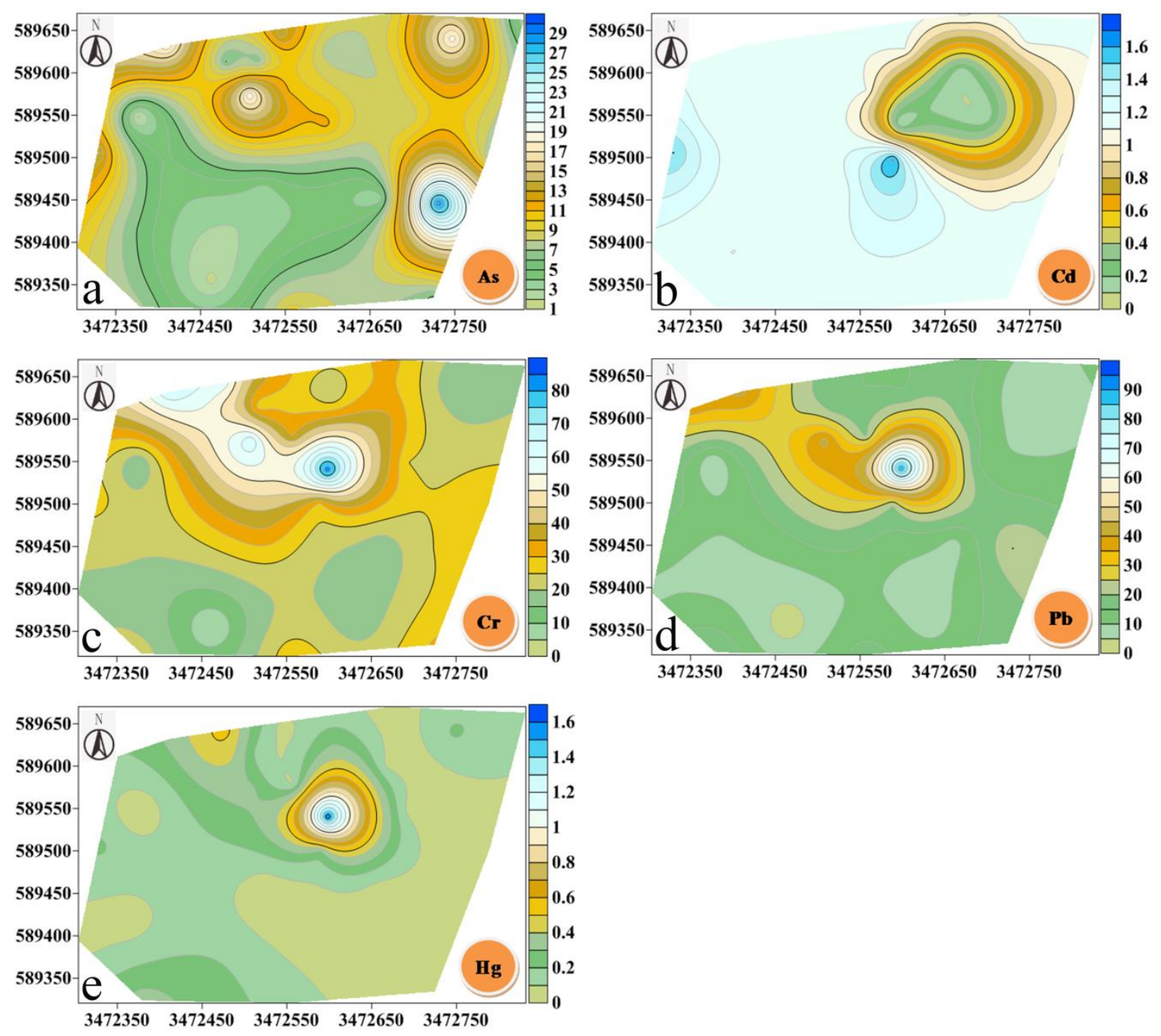

Fig. 2. Spatial distributions of soil heavy metals in the study area using the method of Kriging interpolation.

\subsection{Evaluation of ecological enrichment}

\section{2}

\subsubsection{Enrichment levels of soil heavy metals}

The EF was calculated based on a formula, which was then classified to six levels (Couto et al., 2018). If EF $<1$,

it was defined as class 1 , which meant there was no enrichment; If $1<\mathrm{EF}<2$, it was defined as class 2 , which meant there was minor enrichment; If $2 \leq \mathrm{EF}<5$, it was defined as class 3 , indicating moderate enrichment happened in the area; If $5 \leq \mathrm{EF}<20$, it was defined as class 4, which can be judged that there will be significant enrichment here; If $20 \leq \mathrm{EF}<40$, it was defined as class 5, predicting strong enrichment; If $\mathrm{EF} \geq 40$, it was defined as class 6, showing extremely severe enrichment (Sartipi Yarahmadi and Ansari, 2018). Based on the calculation results exhibited in Fig. S2 and ecological spatial distribution in Fig. 3, it can be concluded that the highest EF value of $\mathrm{Hg}$ is 6.95 at the 
sampling point S8, which was classified as significant enrichment (De Silva etal., 2016). The second metal with high enrichment levels was $\mathrm{Cd}$, with the value of 3.74 at the sampling points $\mathrm{S} 24 . \mathrm{Pb}$ with the value of 3.14 had the third enrichment level, the same as Hg at S8 (Sartipi Yarahmadi and Ansari, 2018). EF values of sampling points S6 and S28 both exceeded 1, except for metal chromium. EF values of metal arsenic at S4, S6, S12, S25, S27 and S28 were greater than 1 and less than 2, so the enrichment degree was slight pollution. However, the EF values of As at the sampling point S15 were higher than 2, indicating moderate enrichment by some factor. The number of sampling points of $\mathrm{Hg}$ slightly enriched as level $1(1<\mathrm{EF}<2)$ was S3, S6, S19, S20, S24 and S28. The sampling points with the value greater than 2 were moderate enrichment.

\subsubsection{PERI levels of the study area}

The ecological risks of soil heavy metals in the area were discussed with the method of potential ecological risk index invented by Hakanson (Guo et al., 2012; Ouyang et al., 2018). Fig. 3 demonstrates the potential ecological risk index distribution of five heavy metals in the topsoil surrounds the dye factory. The $\mathrm{E}_{\mathrm{r}}^{\mathrm{i}}$ values of $\mathrm{As}, \mathrm{Cr}$ and $\mathrm{Pb}$ for all samples were no more than 40 , which indicated that these heavy metals posed a low potential ecological risk. However, the $\mathrm{E}_{\mathrm{r}}^{\mathrm{i}}$ values of metal $\mathrm{Cr}$ both occupied a proportion of $6.67 \%$ of the samples were greater than 40 and 80 , proportion of $26.7 \%, 6.67 \%$ and $3.33 \%$ in the level of moderate, high and severe, respectively. It was worth mentioning that the $\mathrm{E}_{\mathrm{r}}^{\mathrm{i}}$ value of $\mathrm{Hg}$ was 387.73 at the sampling points $\mathrm{S} 8$, which was consistent with $\mathrm{EF}$ value, suggesting anthropogenic activities may have a greater impact on the area. 

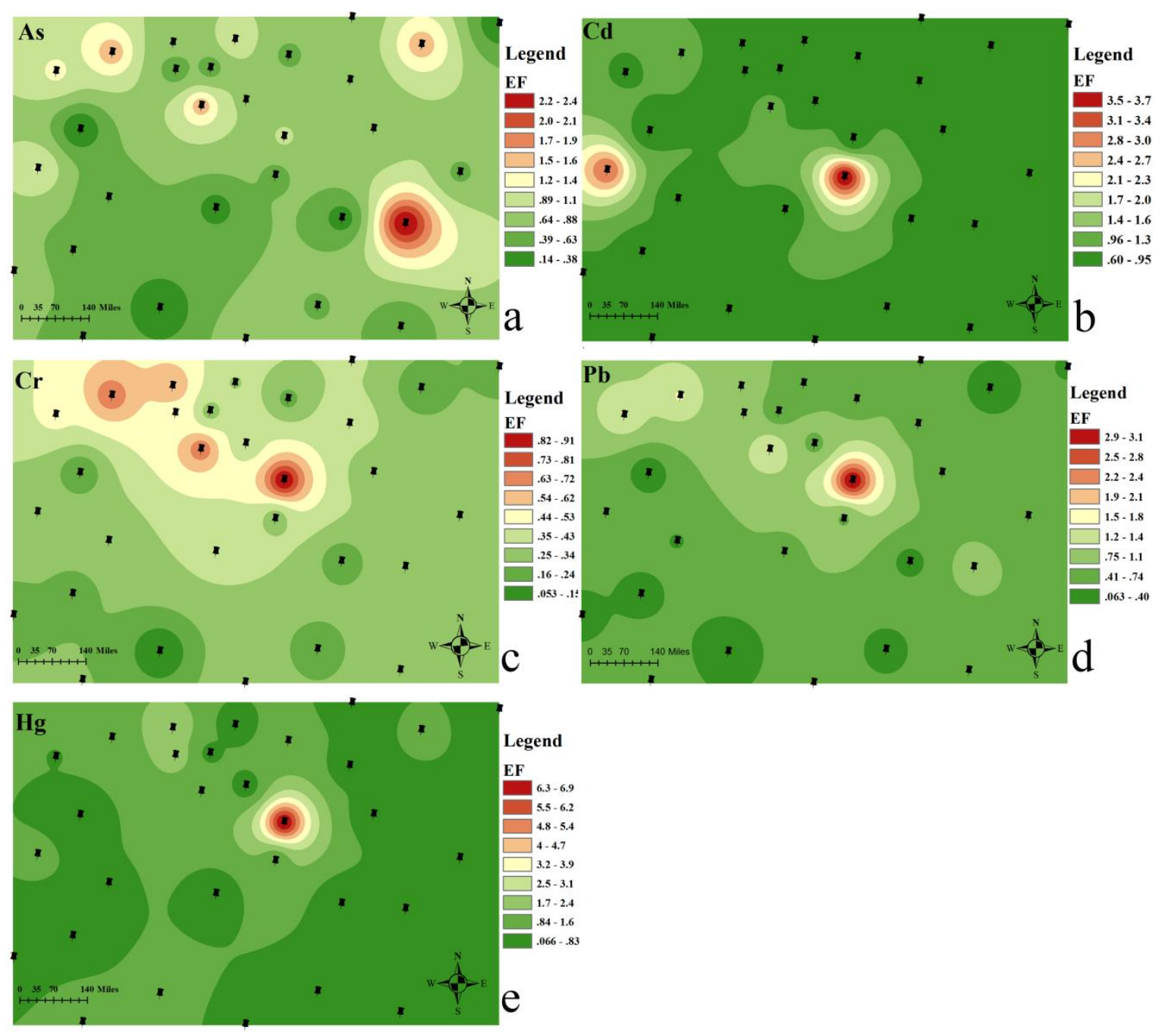

Fig. 3. The ecological spatial distributions of soil heavy metals in the sampling area.

250 According to the RI level of this study, there were three samples where the RI values were less than 300, which

251 indicated a moderate potential ecological risk. It should be noted that $\mathrm{Cd}$ and $\mathrm{Hg}$ contributed $48.91 \%$ and $41.94 \%$ of

252 the total potential ecological risk, respectively. The highest potential ecological risk value at S8 was 451.89 , which

253 appears to be in serious condition here, in which $\mathrm{Hg}$ accounting for $85.8 \%$. Fig. 4a demonstrated that the sequence

254 of potential ecological risks of heavy metals was $\mathrm{RI}>\mathrm{Hg}>\mathrm{Cd}>\mathrm{As}>\mathrm{Pb}>\mathrm{Cr}$. The total potential ecological risk

255 value was 107.5, indicating a low risk level on the whole.

256 3.3. Quantitative source apportionment in the study area

\subsubsection{Factor loading and source identification}


soil (Wang et al., 2019). Six factors were loaded and the percentage of the total number of species was presented in

Fig. S3. Factor 1 accounted for a high percentage of $\mathrm{Hg}(56.6 \%)$ and $\mathrm{Cr}(37.7 \%)$, the high $\boldsymbol{C V}$ of which reflecting that they may be related to anthropogenic sources (Guan et al., 2018). Such as Hg emissions brought about by human activities and the emissions caused by waste treatment. On the other hand, $\mathrm{Cr}$ can be attributed to emissions of vehicle activities from the traffic roads (Parra etal., 2014). Factor 2 was dominated by $\mathrm{Pb}$, with percentage of $24.8 \%$. It was noted that the concentration of $\mathrm{Pb}$ was close to the background value. High concentration distribution of $\mathrm{Pb}$ was mainly concentrated around S8 near the traffic road, which can be inferred that the contaminants were from traffic activities or fossil fuel. Factor 3 explained $52.8 \%$ of the total species to As, which may be due to utilization of agrochemicals (Xiao et al., 2019). Thus because As was the main element in the use of pesticides to farmland (Cai etal., 2015). The high concentration area of As was around the sampling site S15 nearby the farmland on the map (Salim et al., 2019). Previous studies had also confirmed that the enrichment of arsenic was due to the use of pesticides (Liang et al., 2017b). Factor 4 was defined by $\mathrm{Cr}(40.7 \%)$ and $\mathrm{Pb}(36.2 \%)$. The accumulation of $\mathrm{Cr}$ and $\mathrm{Pb}$ was mainly associated fine particles from the road area, including atmospheric deposition, coal burning and metal processing (Wu et al., 2015). Hg accounted for a large proportion in factor 5 with the percentage of $23.6 \%$, the same as the factor 1, which can be concluded that they were from the same sources of pollution. Cd stand out with $67.5 \%$ of factor 6. The high $\boldsymbol{C V}$ value and higher mean concentration compared with the background value, showing the influence of artificial factor (Gao etal., 2018). According to the previous investigation, the textile and dyeing industries attributed high content of $\mathrm{Cd}$ from the emission of the sewage of dyeing activities (Wang et al., 2019; Luo et al., 2011). The high concentration area and high risk area of metal $\mathrm{Cd}$ were all around the dye factory as investigated. Therefore it was concluded that there were six sources of pollution dominating the contaminated site.

\subsubsection{Source contribution}


quantitative source apportionment of soil heavy metals were demonstrated in Fig. $\mathbf{4 b}$. Six factors were extracted by PMF model, the Factor 1 was loaded by $\mathrm{Hg}$ (56.6\%) and $\mathrm{Cr}$ (37.7\%), Factor 2 was dominated by $\mathrm{Pb}$ (24.8\%), Factor 3 was characterized by As (52.8\%), Factor 4 was $\mathrm{Cr}$ (40.7\%) and $\mathrm{Pb}$ (36.2\%), Factor 5 was mainly $\mathrm{Hg}$ (23.6\%), Factor 6 was principally $\mathrm{Cd}(67.5 \%)$.

Comparatively speaking, industrial activities occupied the largest contribution to soil heavy metals in the study area; followed by the human activities such as waste emission. Agricultural activities accounted for the third largest contribution, for the reason of with farmland in the study area. Owing to the frequent utilization of vehicle and fuel near the roads, traffic activities accounted for the fourth largest contribution and the followed one was atmospheric deposition. The results were consistent with the current situation of the whole study area, with abandoned factories, developed transportation around and frequent agricultural activities, indicating the close relationship between the dye factory and its surrounding soil.

a

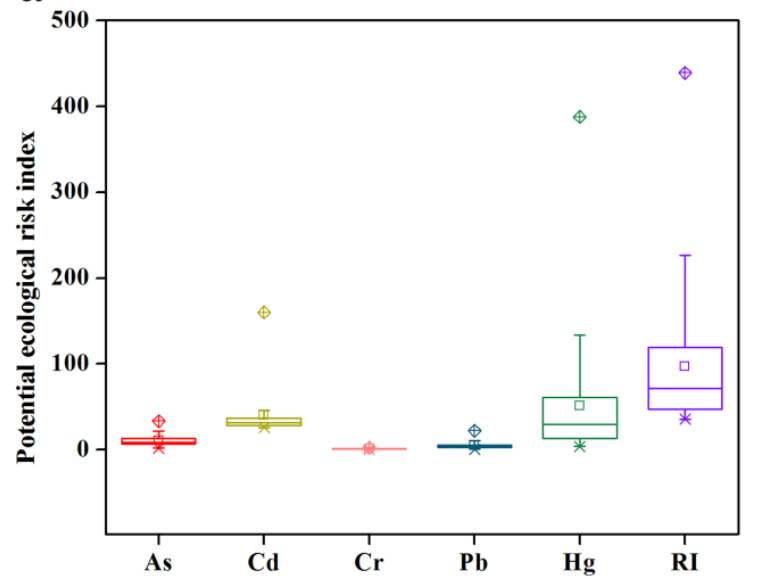

b

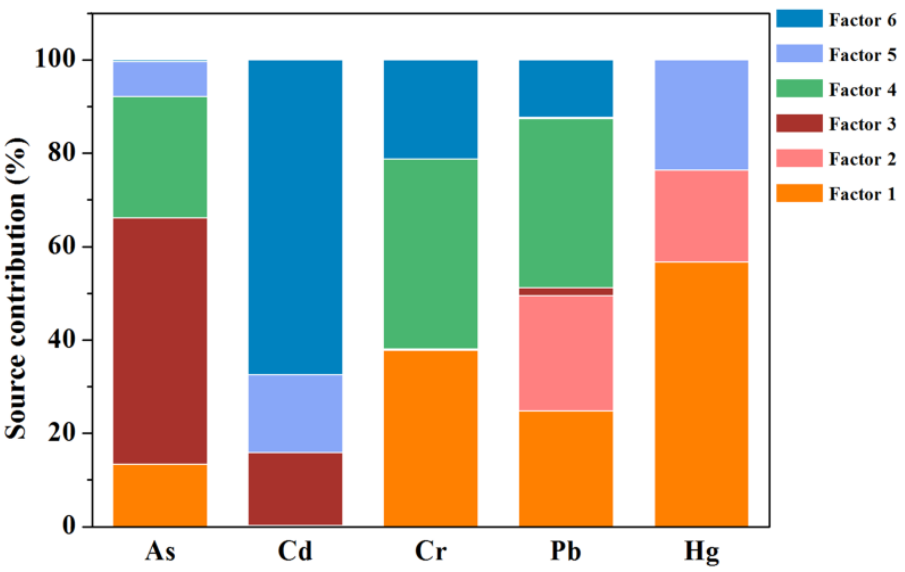

Fig. 4. (a) Box plot of the potential ecological risk and (b) source contributions (\%) for each heavy metal estimated by PMF model.

\subsubsection{Uncertainty analysis}

Monte Carlo analysis was used to investigated the uncertainty analysis by Crystal Ball software (Version 2000,

Decisioning, Denver, CO, USA). 95\% confidence interval was generated for all fitted models. The results showed that each factor of source profile and the output tend to be stable. 


\subsection{Quantifying environmental risk assessment from sources}

\subsubsection{Assessment of PMF-based SCEI}

PMF-based $\boldsymbol{S C E I}$ assessment was applied to quantitatively characterize the relationship between pollutants sources

and $\boldsymbol{R} \boldsymbol{I}$. Optimized source contributed potential ecological risk of each heavy metal in soil were presented in Fig. $\mathbf{5}$.

For $\mathrm{Pb}$, the vehicle source was the major ecological risk sources, accounting $1.76 \mathrm{E}+00$ of the risk. Human activities contributed most to the ecological risk of $\mathrm{Hg}$, with the risk value of $2.89 \mathrm{E}+01$. For $\mathrm{Cr}$, higher risk values were derived from nature (3.6E-01) and traffic sources (3.9E-01). For Cd, the risk values of industrial and waste scores were higher, accounting for $2.69 \mathrm{E}+01$ and $6.6 \mathrm{E}+00$, respectively. The contributions from agriculture accounted for $2.78 \mathrm{E}+00$ to

RI for As. Pollutant sources of $\boldsymbol{S C E I}$ were mainly dominated by human activities and industrial activities, accounting

for 3.19E +01 and $2.78 \mathrm{E}+01$, respectively. Source contributions decreased as follows: human activities $>$ industrial

activities $>$ waste $>$ atmospheric deposition $>$ agriculture activities $>$ vehicle for the total $\boldsymbol{R} \boldsymbol{I}$ of each heavy metal. The modified total $\boldsymbol{S C E I}$ value of $\mathrm{Hg}$ was 51.16, posing moderate ecological effect to the environment and residents nearby. The potential ecological risk value of the optimized pollution source was 107.48 , which was lower than 150 , indicating that the area was at a low risk level. In summary, industrial activities with high $\mathrm{Cd}$ source-oriented ecological risk than other pollution sources would be regarded as the potential source of SCEI. Therefore, great measures should be taken to control the discharge and disposal of pollutants from dye factory, such as textile, 


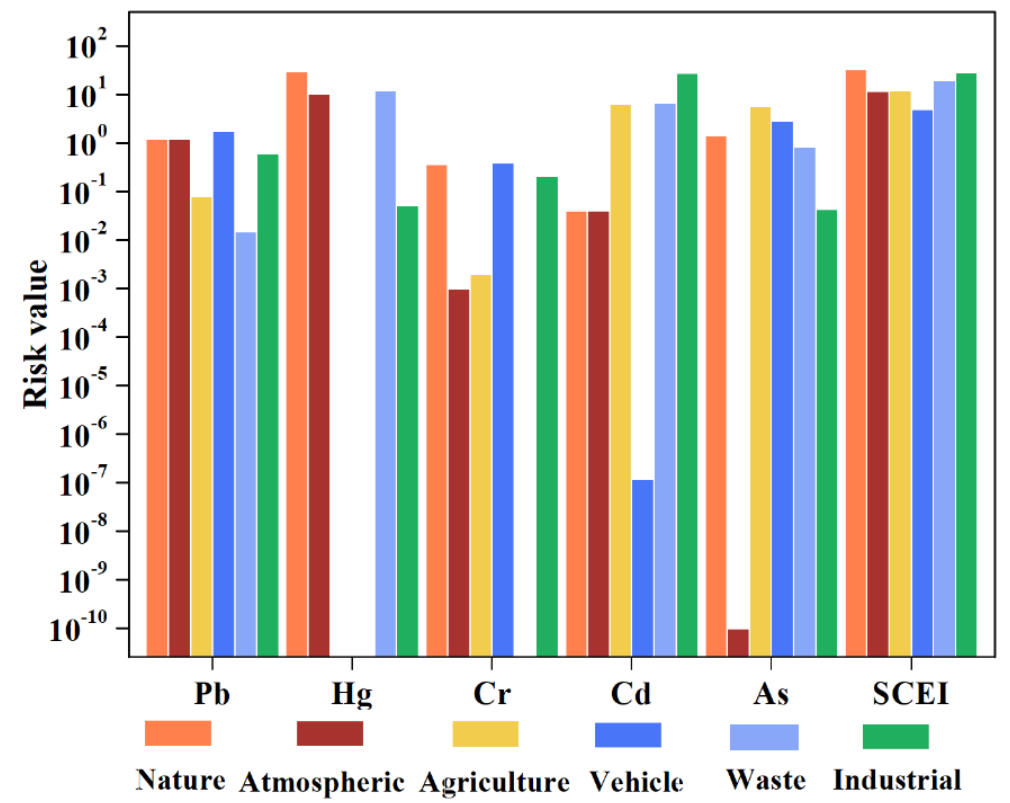

Fig. 5. Source contributions to potential ecological risk index by heavy metals based on SERA method (SCEI: the sum of source contributed RI of five heavy metals).

\subsubsection{Assessment of PMF-based SCHI}

The original data of $\boldsymbol{H Q}, \boldsymbol{H I}$ and $\boldsymbol{T H I}$ (adults and children) by means of classical health risk assessment were presented in Table 2. The highest average intake turned out to be the ingestion pathway and the order followed were: dermal contact $>$ inhalation. In the ingestion pathway, average $\boldsymbol{H} \boldsymbol{Q}$ ranged as: $\mathrm{As}>\mathrm{Cd}>\mathrm{Pb}>\mathrm{Hg}>\mathrm{Cr}$. $\boldsymbol{H} \boldsymbol{Q}$ f for five heavy metals were lower than 1 both for adults and children, indicating that there were no significant health risks. However, the $\boldsymbol{T H I}$ value of children through ingestion pathway was 1.02, higher than 1, showing potential health threat to the children.

The modified assessment of human health risk for five heavy metals was performed based on source contribution (Li etal., 2020). The calculation of $\boldsymbol{S C H I}$ could demonstrate the relationship between pollutants sources and $\boldsymbol{H I}$. Fig. 6 presented source contributions to human health risk index by heavy metals based on SERA method. For Pb, vehicle was the major health risk source, which occupying the value of 4.2E-02. For $\mathrm{Hg}$, human activities (nature) were the largest contribution to health risk, accounting for 5.1E-03, followed by waste (2.1E-03) and atmospheric deposition (1.77E-03). For Cr, risk values of human activities and vehicle were higher, accounting for 2.1E-03 and 1.96E-03. 
331 were dominated by agriculture, vehicle and waste, accounting for 4.5E-01, 2.2E-01 and 1.1E-01, respectively.

332 Agriculture activities turned out to be the predominant source (4.7E-01) among these sources of the total $\boldsymbol{S C H I}$,

333 followed by vehicle (2.66E-01), human activities (1.5E-01), industrial activities (1.03E-01), waste (8.7E-02) and atmospheric deposition (3.1E-02). Therefore, the emission of As should be given much attention by the local

$1.11 \mathrm{E}+00$, showing potential risk to the residents.

Table 2

Estimations of human health risk of soil heavy metals.

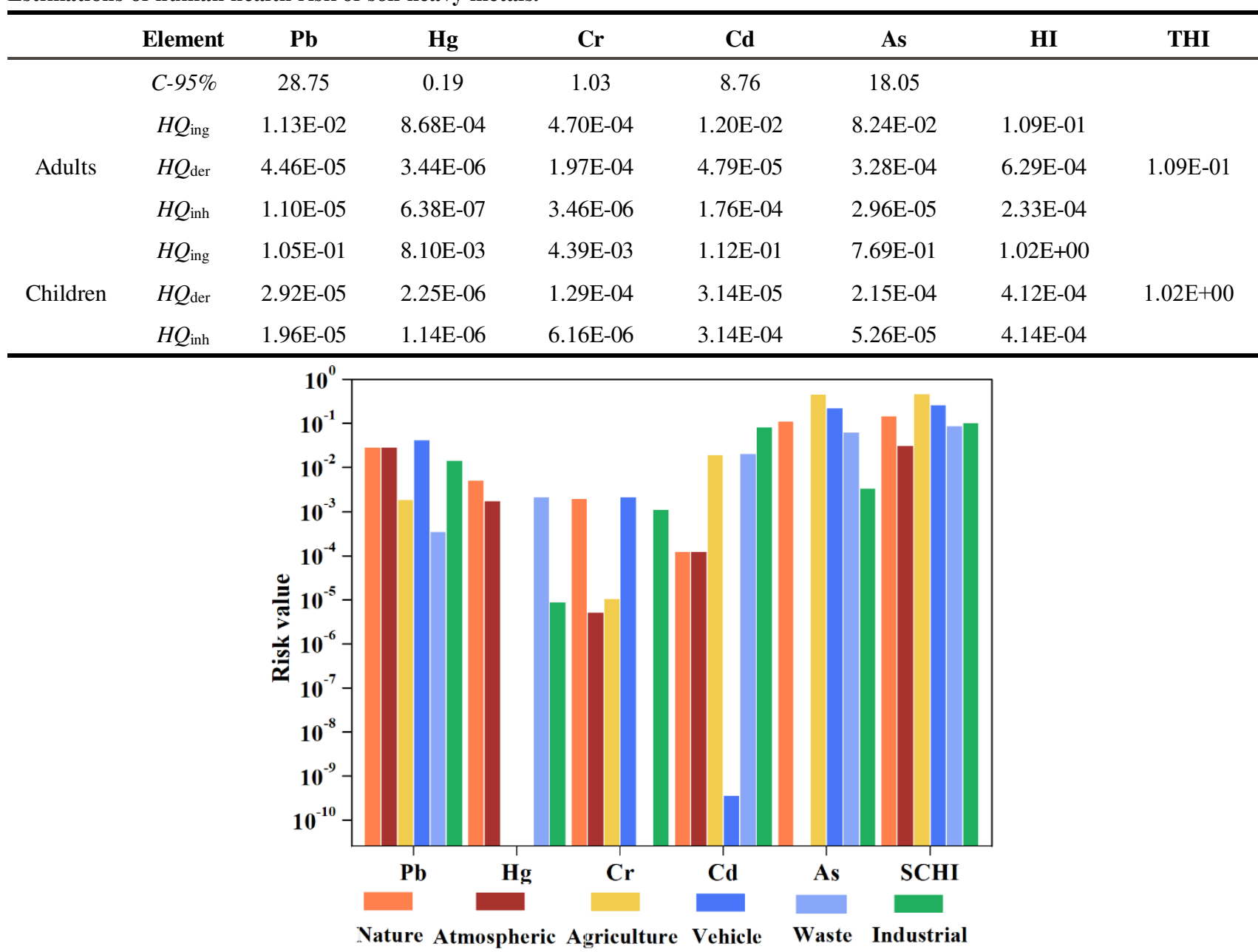

Fig. 6. Source contributions to human health risk index by heavy metals based on SERA method (SCHI: the sum of source contributed 


\subsection{Disscussion of the SERA methodology}

On this basis of the traditional research, risk assessment under the traceability of pollutant sources was added in

this paper. The SERA evaluation model of the risk allocation of pollution sources was constructed, which is constructive for the treatment of heavy metal soil pollution. It has a certain reference value for the supplement and improvement of the environmental risk assessment system.

The comprehensive environmental risk assessment based on source apportionment mainly included ecological risk and human health risk. The pollution sources are quantified for environmental risk assessment, which was optimized compared with conventional risk model. It turned out that the traceability results of the two source-oriented risk assessment model were different as well as the risk contribution order of pollution sources. Source-oriented ecological risk analysis was at a low risk level, which was dominated by industrial activities. Therefore, $\mathrm{Cd}$ should be regarded as the target metal, the emission of which should be converted to hypotoxic elements. It can effectively prevent pollution and realize regional environmental management. Source-oriented human health risk analysis, which was a potential risk level, was dominated by agricultural activities. So metal arsenic should be treated as a priority target metal for soil pollution (Peng etal., 2017). Effective control of metal emission can reduce the level of health risk in this region.

After comprehensive comparison, It came to a conclusion that a single risk assessment method, which may overlook the potential risk of certain heavy metal, is incomplete. The traceability and contribution of certain pollution sources combined with comprehensive environmental risk assessment could make up for these deficiencies. In the comparative study of ecological risk and health risk tracing, it is more reasonable to take a comprehensive risk assessment for consideration. This study provides new insights for the treatment of complex sources of soil heavy metal pollution.

\section{Conclusions}

It is of great significance to study the distribution of heavy metal content in abandoned factories and carry out the 
comprehensive environmental risk assessment of heavy metal, so as to provide the basis for the prevention and control

of soil heavy metal pollution. The SERA method was developed by integrating environmental risk assessment and

source contribution based on source apportionment to study pollutant sources and risk levels. This method optimized

spatial interpolation based on the global content data output so as to quantitatively analyze source contribution. A

case study was carried out in an abandoned dye factory in Suzhou City, China. This study assessed spatial distribution

characteristic, ecological enrichment and environmental risk of five heavy metals $(\mathrm{Pb}, \mathrm{Hg}, \mathrm{Cr}, \mathrm{Cd}, \mathrm{As})$ in the study area. PMF model was utilized to apportion the sources of risk, combining a receptor model and a risk model. The potential ecological risk and human health risk of heavy metals for each source category were also discussed, in which some interesting results were found. Results showed the potential ecological risk was low risk level, which was consistent with the modified potential ecological risk assessment (SCEI model). However, owing to anthropogenic influence, the area was contaminated by these heavy metals studied in some degree. Particularly, industrial activities were identified as the largest contributor of $\mathrm{Cd}$ source-oriented ecological risk, mainly associating with the discharge and disposal of pollutants from the dye factory in the area. The results of source-contributed health risk ( $\boldsymbol{S C H I}$ model) suggested that there was potential health threat to the children. As of agriculture activities contributed most to the risk level and would lead to higher risks in the study area. After comprehensive comparison,

it is concluded that in the comparative study after tracing ecological risks and health risks, it is more reasonable to use comprehensive site environmental risk assessment to treat regional pollution sources in this region. This study provides a new insight for the treatment of multi-sources of heavy metal and it is advised to reduce the total emission in the process of industry and agriculture by regional structural reconstruction.

\section{Acknowledgments}

This work was financially supported by the National Key R\&D Program of China (No. 2018YFB0605504) and the National Natural Science Foundation of China (Grant No. 51878272). This work is supported by MOE Key 
their heartfelt gratitude to the support of NationalUniversity of Singapore Suzhou research institute. Sincere gratitude

should be expressed to the editors and reviewers who have put considerable time and efforts into their comments on

this paper.

\section{References:}

Adimalla, N., Qian, H., Wang, H.K., 2019. Assessment of heavy metal (HM) contamination in agricultural soil lands in northern Telangana, India: an approach of spatial distribution and multivariate statistical analysis. Environ.Monit. Assess. $191,246$. https://doi.org/10.1007/s10661-019-7408-1.

Barbieri, M,.2016. The Importance of Enrichment Factor (EF) and Geoaccumulation Index (Igeo) to Evaluate the Soil Contamination. J. Geol. Geophys. 5(1). https://doi.org/10.4172/2381-8719.1000237.

Bryanin, S.V., Sorokina, O.A., 2019. Effect of soil properties and environmental factors on chemical compositions of forest soils in the Russian Far East. J. Soils Sediments 19, 1130-1138. https://doi.org/ 10.1007/s11368-018-2141-x.

Cai, L., Xu, Z., Bao, P., He, M., Dou, L., Chen, L., Zhou, Y., Zhu, Y.G., 2015. Multivariate and geostatistical analyses of the spatial distribution and source of arsenic and heavy metals in the agricultural soils in Shunde, Southeast China. J. Geochem.Explor. 148, 189-195. https://doi.org/10.1016/j.gexplo.2014.09.010.

Chen, J.Q.,Wang, Z.X.,Wu, X., Zhu, J.J., Zhou,W.B., 2011. Source and hazard identification of heavy metals in soils of Changsha based on TIN model and direct exposure method. Trans. Nonferrous Metals Soc. China 21 (3), 642-651. https://doi.org/10.1016/S10036326(11)60761-9.

Chen, Y.X., Jiang, X.S., Wang, Y., Zhuang, D.F., 2018. Spatial characteristics of heavy metal pollution and the potential ecological risk of a typical mining area: a case study in China. Process Saf. Environ. Prot. 113, 204-219. https://doi.org/10.1016/j.psep.2017.10.008.

Cheng, S., Liu, G., Zhou, C., Sun R., 2018. Chemical speciation and risk assessment of cadmium in soils around a typical coal mining area of China. Ecotox. Environ. Safe. 160, 67-74. https://doi.org/10.1016/j.ecoenv.2018.05.022.

CNEPA (National Environment Protection Agency of China), 1995, Environment Quality Standard for Soils (GB 15618-1995) (in Chinese).

Couto, RDR., Faversani, J., Ceretta, CA., Ferreira, PAA., Brunetto, G., 2018. Health risk assessment and soil and plant heavy metal and bromine contents in field plots after ten years of organic and mineral fertilization. Ecotox. Environ. Safe. 153, 142-150. https://doi.org/10.1016/j.ecoenv.2018.01.046.

CSC (China State Council), 2016. The action plan for soil pollution prevention and control. Available at: http://www.gov.cn/zhengce/content/2016-05/31/content_5078377.htm (accessed in November) (in Chinese).

De Miranda, R.M., de Fatima Andrade, M., Dutra Ribeiro, F.N., Mendonça Francisco, K.J., Pérez-Martínez, P.J., 2018, Source apportionment of fine particulate matter by positive matrix factorization in the metropolitan area of São Paulo, Brazil. J. Clean Prod. 
De Silva, S., Ball, A.S., Huynh, T., Reichman, S.M., 2016. Metal accumulation in roadside soil in Melbourne, Australia: effect of road age, traffic density and vehicular speed. Environ. Pollut. 208, 102-109. https://doi.org/10.1016/j.envpol.2015.09.032.

Dong, R.Z., Jia, Z.M., Li, S.Y., 2018. Risk assessment and sources identification of soil heavy metals in a typical county of Chongqing municipality, Southwest China. Process Saf. Environ. Prot. 113, 275-281. https://doi.org/10.1016/j.psep.2017.10.021.

Duan, J.C., Tan, J.H., Hao, J.M., Chai, F.H., 2014. Size distribution, characteristics and sources of heavy metals in haze episod in Beijing. J. Environ. Sci. 26, 189-196. https://doi.org/10.1016/S1001-0742(13)60397-6.

Duan, Y.X., Zhang, Y.M., Li, S., Fang, Q.L., Miao, F.F., Lin, Q.G., 2020, An integrated method of health risk assessment based on spatial interpolation and source apportionment. J. Clean Prod. 276. https://doi.org/10.1016/j.jclepro.2020.123218.

Franco-Uría, A., López-Mateo, C., Roca, E., Fernández-Marcos, M.L., 2009. Source identification of heavy metals in pastureland by multivariate analysis in NW Spain. J. Hazard. Mater. 165, 1008-1015. https://doi.org/10.1016/j.jhazmat.2008.10.118.

Fu, WJ., Jiang, PK., Zhou, GM., Zhao, KL.,2014. Using Moran's I and GIS to study the spatial pattern of forest litter carbon density in a subtropical region of southeastern China. Biogeosciences. 11, 2401-2409. https://doi.org/10.5194/bg-11-2401-2014.

Gao, J., Wang, L.C., 2018. Ecological and human health risk assessments in the context of soil heavy metal pollution in a typical industrial area of Shanghai, China. Environ. Sci. Pollut. Res. 25, 27090-27105. https://doi.org/10.1007/s11356-018-2705-8.

Guan, Q., Wang, F., Xu, C., Pan, N., Lin, J., Zhao, R., 2018. Source apportionment of heavy metals in agricultural soil based on PMF: A case study in Hexi Corridor, northwest China. Chemosphere 193, 189-197. https://doi.org/10.1016/j.chemosphere.2017.10.151.

Guo, G., Wu, F., Xie, F., Zhang, R., 2012. Spatial distribution and pollution assessment of heavy metals in urban soils from southwest China. J Environ Sci. 24,410-418. https://doi.org/10.1016/S1001-0742(11)60762-6.

Hakanson, L., Håkanson, L., Hakansonn, L., 1980. An ecological risk index for aquatic pollution control: a sediment ecological approach. Water Res. 14, 975-1001. https://doi.org/10.1016/0043-1354(80)90143-8.

Han, Y.M., Du, P.X., Cao, J.J., Posmentier, E.S., 2006. Multivariate analysis of heavy metal contamination in urban dusts of Xi'an, Central China. Sci. Total Environ. 355, 176-186. https://doi.org/10.1016/j.scitotenv.2005.02.026.

Hu,W., Wang, H., Dong, L., Borggaard, O.K., Hansen, H.C.B., He, Y., Holm, P.E., 2018. Source identification of heavy metals in periurban agricultural soils of southeast China: an integrated approach. Environ. Pollut. 237, 650-661. https://doi.org/10.1016/j.envpol.2018.02.070.

Huang, B., Shi, X.Z., Yu, D.S., Oborn, I., Blomback, K., Pagella, T.F., Wang, H.J.,Sun, W.X., Sinclair, F.L., 2006. Environmental. assessment of small-scale vegetable farming systems in peri-urban areas of the Yangtze River Delta Region, China. Agric. Ecosyst. Environ. 112, 391-402. https://doi.org/10.1016/j.agee.2005.08.037.

Ihedioha, J.N., Ukoha, P.O., Ekere, N.R., 2017. Ecological and human health risk assessment of heavy metal contamination in soil of a municipal solid waste dump in Uyo, Nigeria. Environ. Geochem. Health 39, 497-515. https://doi.org/10.1007/s10653-016-9830-4. 
Islam, S., Ahmed, K., Mamun, H.A., Eaton, D.W., 2017. Human and ecological risks of metals in soils under different land use in an urban environment of Bangladesh. Pedosphere, S1002016017603953. https://doi.org/10.1016/S1002-0160(17)60395-3.

Jiang, F., Ren, B.Z., Hursthouse, A., Deng, R.J., Wang, Z.H., 2019. Distribution, source identification, and ecological-health risks of potentially toxic elements (PTEs) in soil of thallium mine area (southwestern Guizhou, China). Environ. Sci. Pollut. Res. 26, 1655616567. https://doi.org/10.1007/s11356-019-04997-3.

Kumar. V., Sharma. A., Kaur, P., Sidhu, GPS., Bali, AS., Bhardwaj, R., 2019. Pollution assessment of heavy metals in soils of India and ecological risk assessment: A state-of-the-art. Chemosphere 216, 449-462. https://doi.org/10.1016/j.chemosphere.2018.10.066.

Larsen, R.K., Baker, J.E., 2003, Source apportionment of polycyclic aromatic hydrocarbons in the urban atmosphere: a comparis on of three methods. Environ. Sci. Technol. 37, 1873-1881. https://doi.org/10.1021/es0206184.

Li, Y.Z., Chen, H.Y., Teng,Y.G., 2020, Source apportionment and source-oriented risk assessment of heavy metals in the sediments of an urban river-lake system. Sci Total Environ.140310. https://doi.org/10.1016/j.scitotenv.2020.140310.

Liang, J., Feng, C., Zeng, G., Gao, X., Zhong, M., Li, X., 2017a. Spatial distribution and source identification of heavy metals in surface soils in a typical coal mine city, Lianyuan, China. Environ. Pollut. 225, 681-690. https://doi.org/10.1016/j.envpol.2017.03.057.

Liang, J., Feng, C., Zeng, G., Gao, X., Zhong, M., Li, X., 2017b. Spatial distribution and source identification of heavy metals in surface soils in a typical coal mine city, Lianyuan, China. Environ Pollut. 225, 681-690. https://doi.o rg/10.1016/j.envpol.2017.03.057.

Liu, X., Ying, L., Lu, S., 2018, Occurrence of typical antibiotics and source analysis based on PCA-MLR method in the East Dongting Lake, China. Ecotox. Environ. Safe. 163, 145-152. https://doi.org/10.1016/j.ecoenv.2018.07.067.

Luo, C., Liu C., Wang, Y., Liu, X., Li, F., Zhang, G.,2011. Heavy metal contamination in soils and vegetables near an e-waste processing site, South China. J Hazard Mater. 186, 481-90. https://doi.org/10.1016/j.jhazmat.2010.11.024.

Lv, J.S., 2019. Multivariate receptor models and robust geostatistics to estimate source apportionment of heavy metals in soils. Environ. Pollut. 244, 72-83. https://doi.org/10.1016/j.scitotenv.2005.02.026.

Ma, Z., Chen, K., Li, Z., Bi, J., Huang, L., 2015. Heavy metals in soils and road dusts in the mining areas of Western Suzhou, China: a preliminary identification of contaminated sites. J SOIL SEDIMENT 16, 204-214. https://doi.org/10.1007/s11368-015-1208-1.

Mamut, A., Eziz, M., Mohammad, A., Anayit, M., 2017. The spatial distribution, contamination, and ecological risk assessment of heavy metals of farmland soils in Karashahar-Baghrash oasis, northwest China. Hum. Ecol. Risk Assess. 23, $1300-1314$. https://doi.org/info:doi/10.1080/10807039.2017.1305263.

National Environmental Protection Agency (NEPA), 1995. Environmental Quality Standard for Soils (GB 15618-1995). National Environmental Protection Agency of China, Beijing.

Nazzal, Y., Howari, FM., Jafri, MK., Naeem, M., Ghrefat, H., 2016. Risk assessment through evaluation of potentially toxic metals in the surface soils of the Qassim area, Central Saudi Arabia. Ital. J. Geosci. 135, 210-216. https://doi.org/10.3301/IJG.2015.10.

Norris, G., Duvall, R., Brown, S., Bai, S., 2014. EPA Positive Matrix Factorization (PMF) 5.0 Fundamentals and User Guide. US Environmental Protection Agency, Washington, DC. 
Ouyang, Z., Gao, L., Yang, C., 2018. Distribution, sources and influence factors of polycyclic aromatic hydrocarbon at different depths of the soil and sediments of two typical coal mining subsidence areas in Huainan, China. Ecotox. Environ. Safe. 163, 255-265. https://doi.org/10.1016/j.ecoenv.2018.07.024.

Paatero, P., Tapper, U., 1994. Positive matrix factorization: a non-negative factor model with optimal utilization of error estimates of data values. Environmetrics 5, 111-126. CCC 1 180-4009/94/020 $111-16$.

Pan, L.B., Ma, J., Wang, X.L., Hou, H., 2016. Heavy metals in soils from a typical county in Shanxi Province, China: levels, sources and spatial distribution. Chemosphere 148, 248-254. https://doi.org/10.1016/i.chemosphere.2015.12.049.

Parra, S., Bravo, M.A., Quiroz, W., Moreno, T., Karanasiou, A., Font, O., Vidal, V., Cereceda-Balic, F., 2014. Source apportionment for contaminated soils using multivariate statistical methods. Chemom. Intell. Lab. Syst. 138, 127-132. https://doi.org/ 10.1016/j.chemolab.2014.08.003.

Peng, X., Shi, G.L., Liu, G.R., Xu, J., Tian, Y.Z., Zhang, Y.F., Feng, Y.C., Russell, A.G., 2017, Source apportionment and heavy metal health risk (HMHR) quantification from sources in a southern city in China, using an ME2-HMHR method. Environ. Pollut. 221, 335-342. https://doi.org/10.1016/j.envpol.2016.11.083.

Salim, I., Sajjad, RU., Paule-Mercado, MC., Memon, SA., Lee, BY., Sukhbaatar C., 2019. Comparison of two receptor models PCAMLR and PMF for source identification and apportionment of pollution carried by runoff from catchment and sub-watershed areas with mixed land cover in South Korea. Sci Total Environ. 663, 764-775. https://doi.org/10.1016/j.scitotenv.2019.01.377.

Sartipi, Yarahmadi S., Ansari, MR., 2018. Ecological risk assessment of heavy metals ( $\mathrm{Zn}, \mathrm{Cr}, \mathrm{Pb}, \mathrm{As}$ and $\mathrm{Cu})$ in sediments of Dohezar River, North of Iran, Tonekabon city. Sheng Tai Xue Bao S1872203217300707. https://doi.org/10.1016/j.chnaes.2017.06.018.

Sun, L., Guo, D.K., Liu, K., Meng, H., Zheng, Y.J., Yuan, F.Q., Zhu, G.H., 2019. Levels, sources, and spatial distribution of heavy metals in soils from a typical coal industrial city of Tangshan, China. Catena 175, 101-109. https://doi.org/10.1016/j.catena.2018.12.014.

Tian, K., Huang, B., Xing, Z., Hu, W., 2017. Geochemical baseline establishment and ecological risk evaluation of heavy metals in greenhouse soils from Dongtai, China. Ecol. Indic. 72, 510-520. https://doi.org/10.1016/j.ecolind.2016.08.037.

Tian, S., Liang, T., Li, K., Wang, L., 2018, Source and path identification of metals pollution in a mining area by PMF and rare earth element patterns in road dust. Sci. Total. Environ. 633, 958-966. https://doi.org/10.1016/j.scitotenv.2018.03.227.

USEPA (United States Environmental Protection Agency), 2014. EPA positive matrix factorization (PMF) 5.0 fundamentals and user guide. In: Norris, G., Duvall, R., Brown, S., Bai, S. (Eds.), EPA/600/R-14/108 (NTIS PB2015-105147), Washington, DC.

Wang, S., Cai, L.M., Wen, H.H., Luo, J., Wang, Q.S., Liu, X., 2018. Spatial distribution and source apportionment of heavy metals in soil from a typical county-level city of Guangdong Province, China. Sci Total Environ. 655, 92-101. https://doi.org/ $\underline{10.1016 / j . s c i t o t e n v .2018 .11 .244 . ~}$

Wang, S., Cai, L., Wen, H., Luo, J., Wang, Q., Liu, X., 2019a. Spatial distribution and source apportionment of heavy metals in soil from a typical county-level city of Guangdong Province, China. Sci. Total. Environ. 655, 92-101. https://doi.org/10.1016/j.scitotenv.2018.11.244. 
Wang, S., Hu, G., Yan, Y., Wang, S., Yu, R., Cui, J., 2019b, Source apportionment of metal elements in PM2.5 in a coastal city in Southeast China: Combined Pb-Sr-Nd isotopes with PMF method. Atmos. Environ. 198, $302-312$. https://doi.org/10.1016/j.atmosenv.2018.10.056.

Wu, Q., Leung, JYS., Geng, X., Chen, S., Huang, X., Li, H., 2015. Heavy metal contamination of soil and water in the vicinity of an abandoned e-waste recycling site: Implications for dissemination of heavy metals. Sci Total Environ. 506, 217-225. https://doi.org/ $\underline{10.1016 / \text { j.scitotenv.2014.10.121. }}$.

Xiao, R., Guo, D., Ali, A., Mi, S., Liu, T., Ren, C., 2019. Accumulation, ecological-health risks assessment, and source apportionment

Xie, Z., Xiang, L., Du, Z., Jiang, Y., Zhang, H., Wu, Y., Long, T., 2016. Accumulation of heavy metals in a coastal wetland natural reserve

Wu,W., Dong, C.,Wu, J., Liu, X.,Wu, Y., Chen, X., Yu, S., 2017. Ecological effects of soil properties and metal concentrations on the composition and diversity of microbial communities associated with land use patterns in an electronic waste recycling region. Sci. Total Environ. 601, 57-65. https://doi.org/10.1016/j.scitotenv.2017.05.165. of heavy metals in paddy soils: A case study in Hanzhong, Shaanxi, China. Environ. Prot. 248, 349-357. https://doi.org/ 10.1016/j.envpol.2019.02.045. in the estuarine wetlands of Tianjin, China. In: 2016 International Congress on Computation Algorithms in Engineering (Iccae 2016), pp. 271-280.

Zhao, L., Xu, Y., Hou, H., Shangguan, Y., Li, F., 2014. Source identification and health risk assessment of metals in urban soils around the Tanggu chemical industrial district, Tianjin, China. Sci. Total Environ. 468, 654-662. https://doi.org/10.1016/j.scitotenv.2013.08.094.

Zhu, H.N., Yuan, X.Z., Zeng, G.M., Jiang, M., Liang, J., Zhang, C., 2012. Ecological risk assessment of heavy metals in sediments of Xiawan port based on modified potential ecological risk index. Trans. Nonferrous Metals Soc. China 22, 1470-1477. https://doi.org/ $\underline{10.1016 / \mathrm{S} 1003-6326(11) 61343-5}$. 


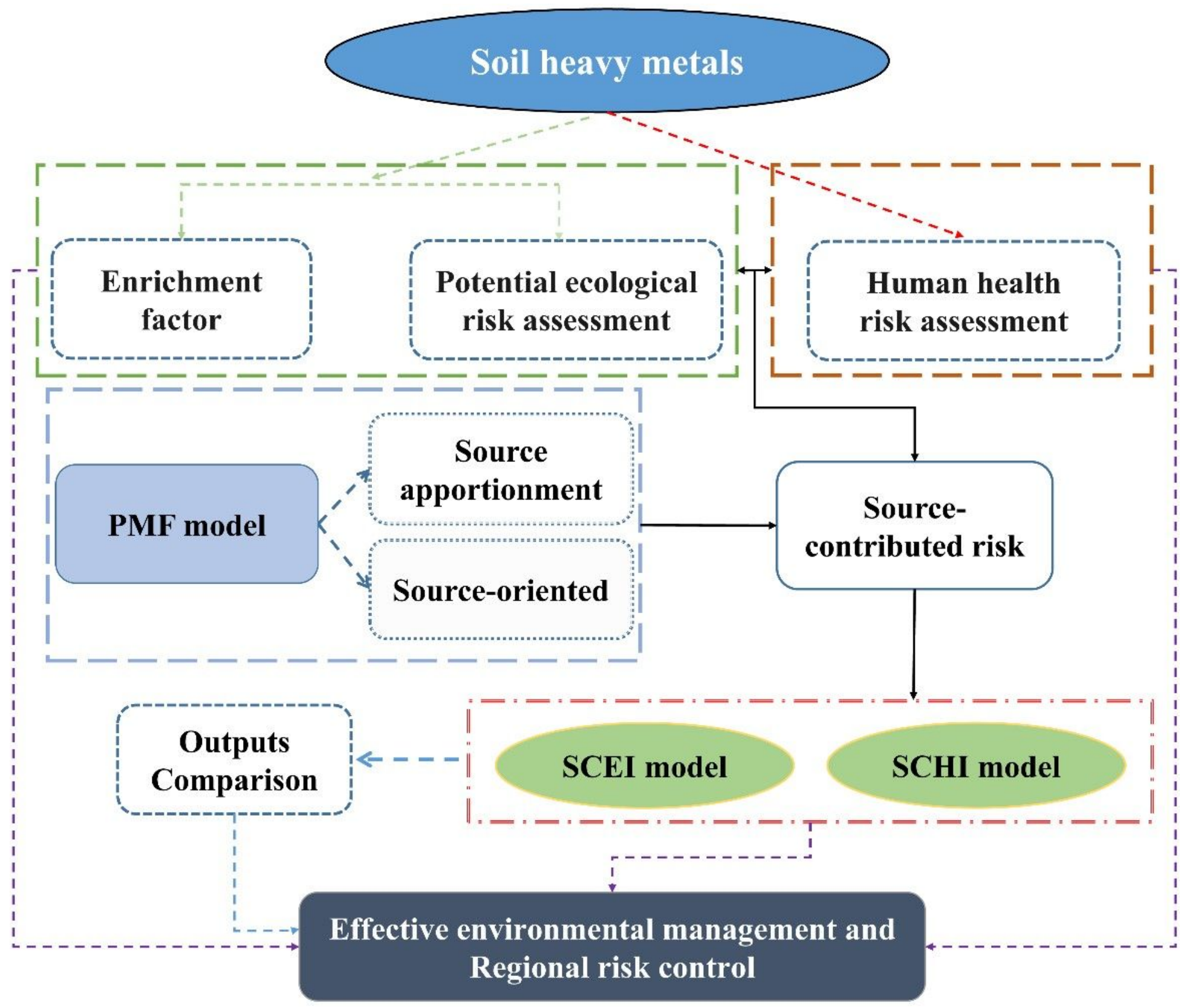

Figure 1

Frameworks of the source apportionment and environmental risk assessment methodology (SERA). SCEI model: source-contributed ecological risk index model; $\mathrm{SCHI}$ model: source-contributed health risk index model. 

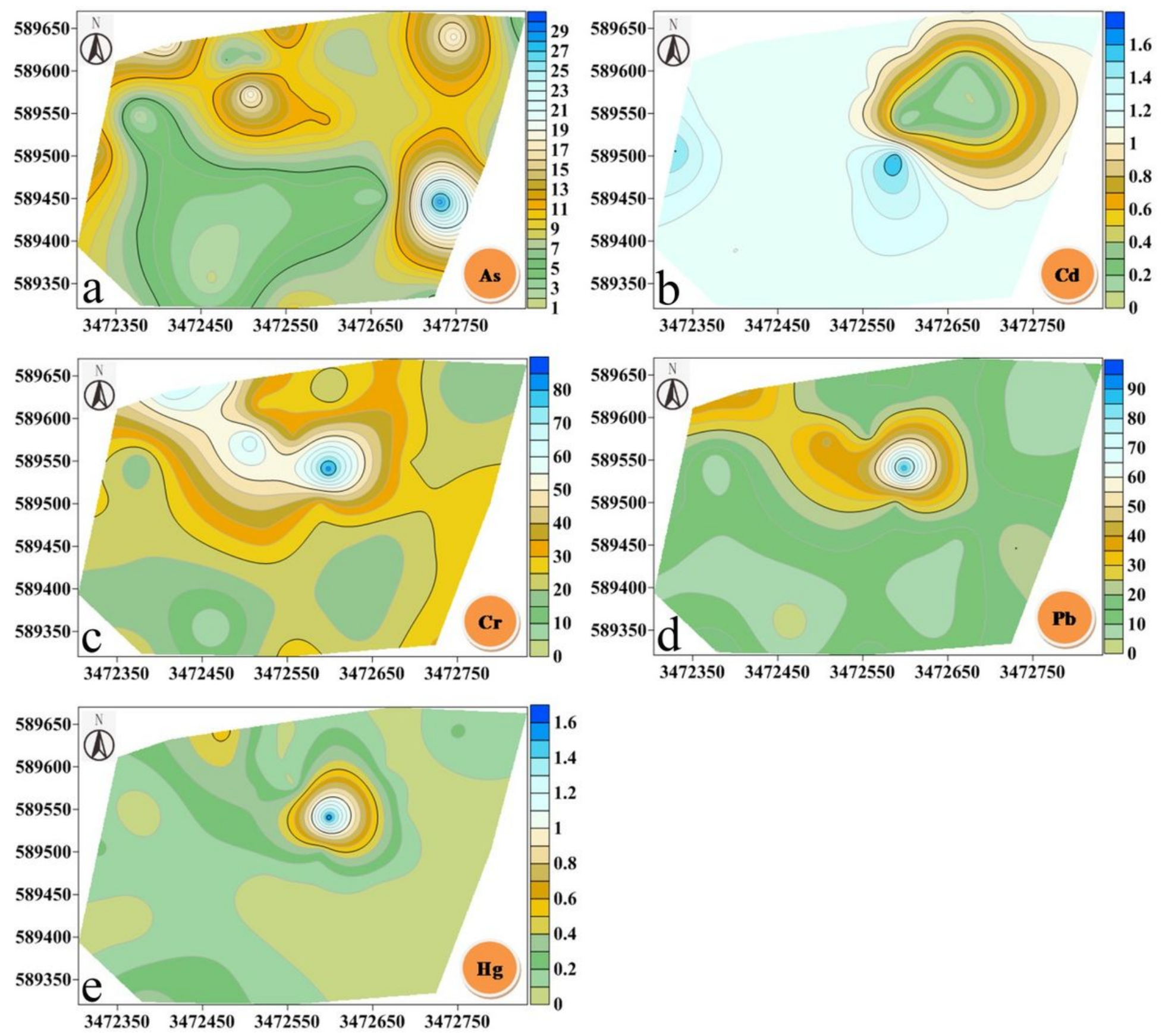

Figure 2

Spatial distributions of soil heavy metals in the study area using the method of Kriging interpolation. Note: The designations employed and the presentation of the material on this map do not imply the expression of any opinion whatsoever on the part of Research Square concerning the legal status of any country, territory, city or area or of its authorities, or concerning the delimitation of its frontiers or boundaries. This map has been provided by the authors. 


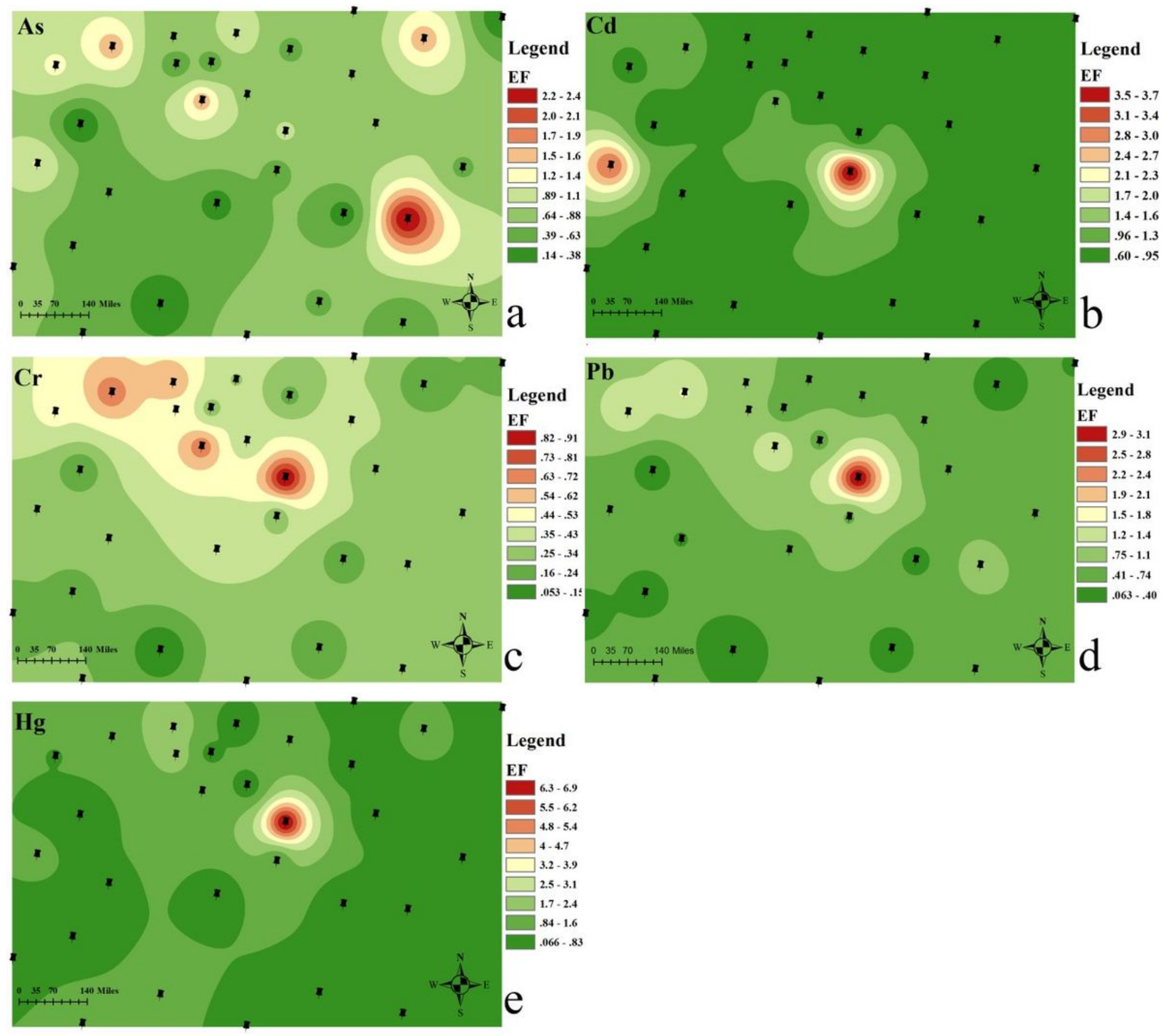

Figure 3

The ecological spatial distributions of soil heavy metals in the sampling area. Note: The designations employed and the presentation of the material on this map do not imply the expression of any opinion whatsoever on the part of Research Square concerning the legal status of any country, territory, city or area or of its authorities, or concerning the delimitation of its frontiers or boundaries. This map has been provided by the authors. 

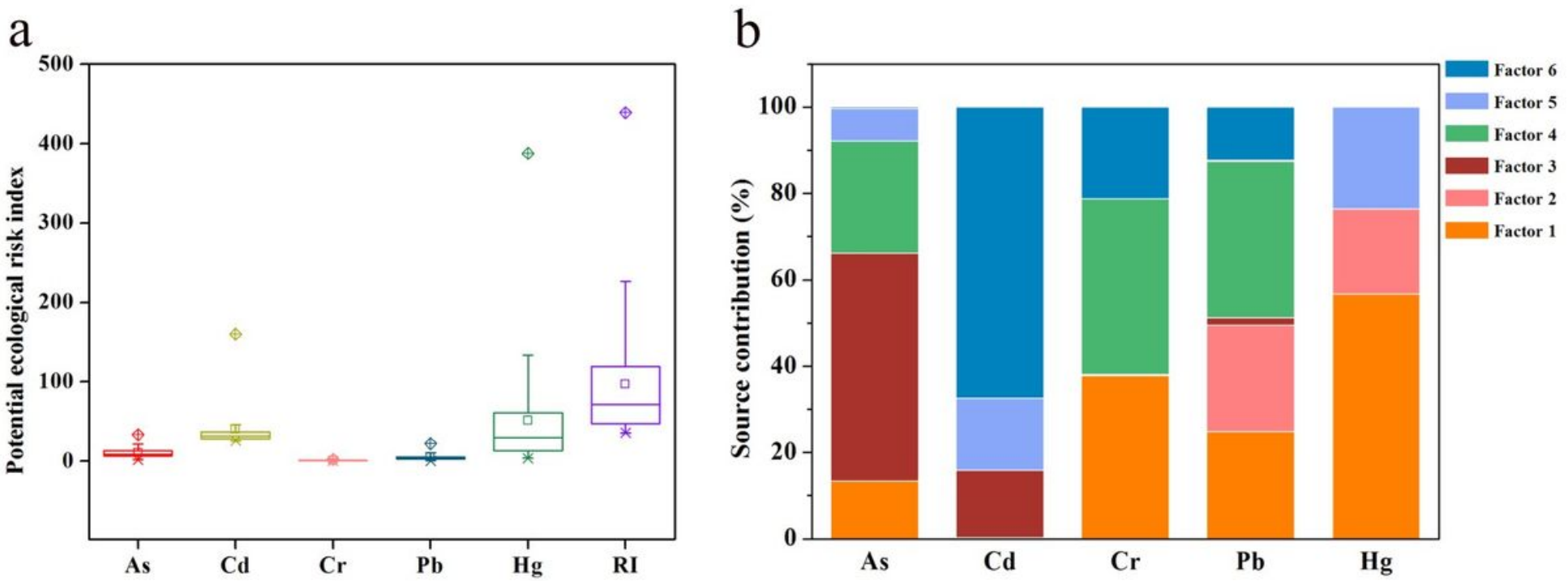

Figure 4

(a) Box plot of the potential ecological risk and (b) source contributions (\%) for each heavy metal estimated by PMF model. 


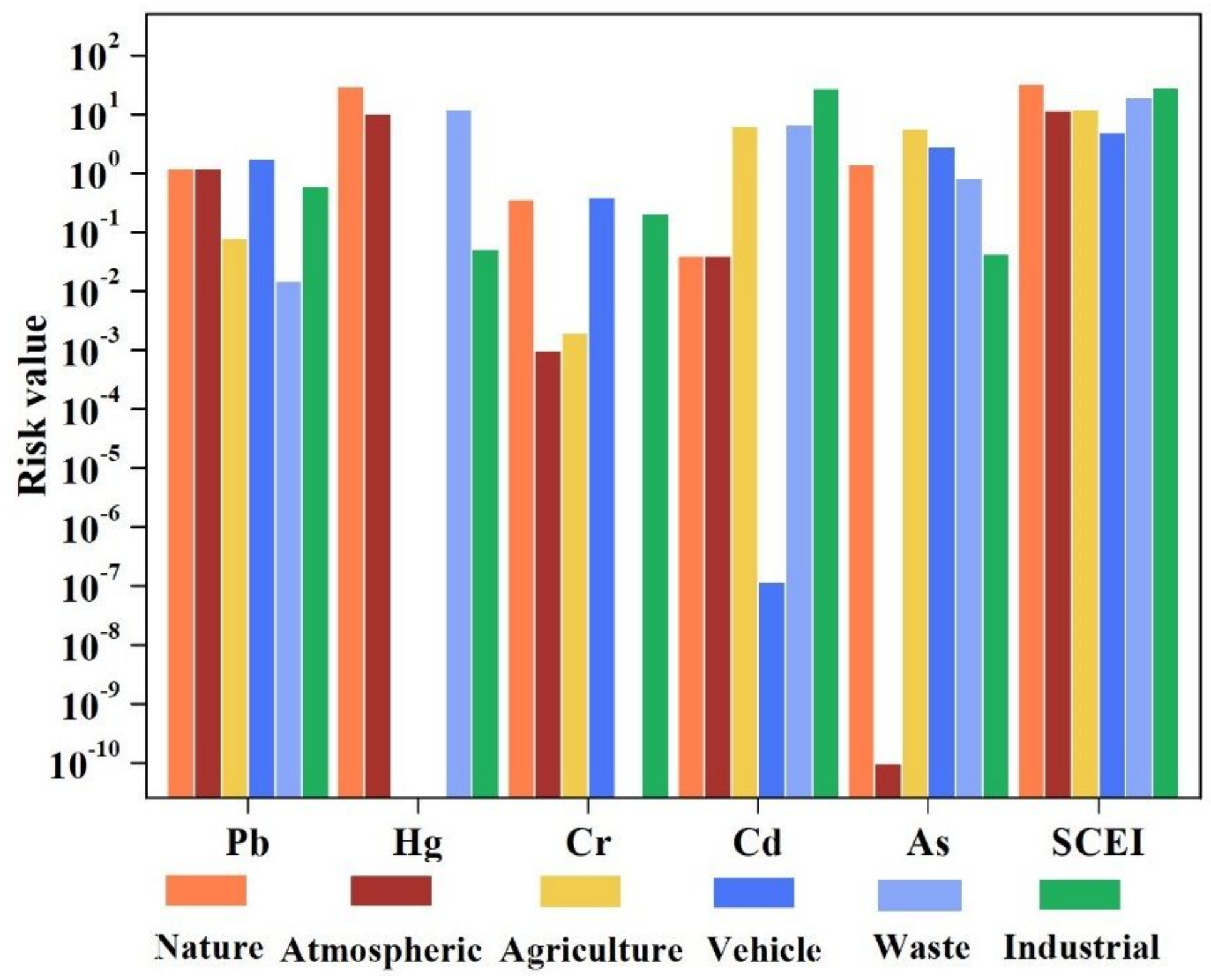

Figure 5

Source contributions to potential ecological risk index by heavy metals based on SERA method (SCEI: the sum of source contributed RI of five heavy metals). 


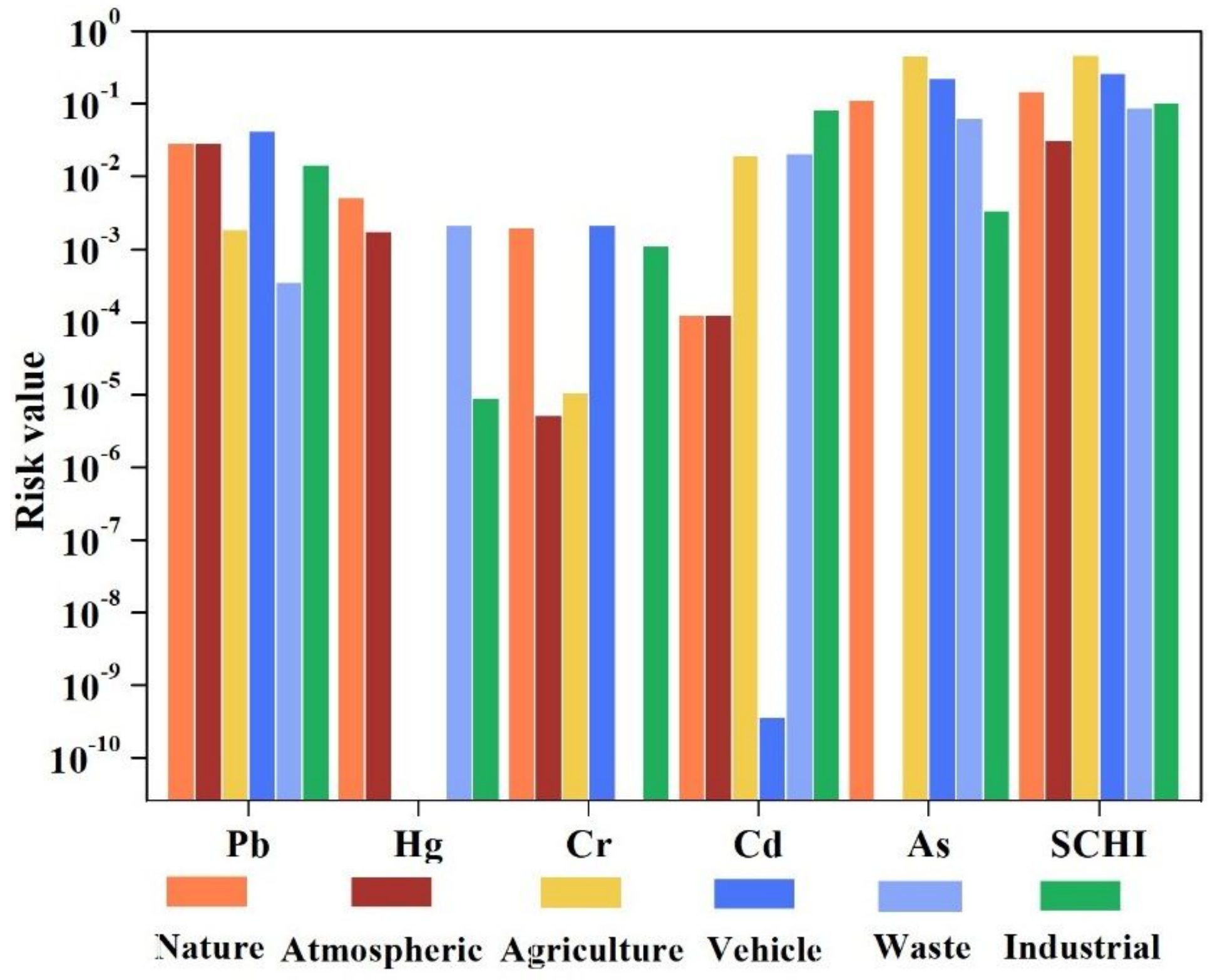

Figure 6

Source contributions to human health risk index by heavy metals based on SERA method (SCHI: the sum of source contributed $\mathrm{HI}$ of five heavy metals).

\section{Supplementary Files}

This is a list of supplementary files associated with this preprint. Click to download.

- GraphicalAbstract.tif

- SuppplementaryMaterial.docx 